研究課題別評価

1 研究課題名:筋肉タンパク自己組織化ゲルによるソフトナノマシンの創製

2 研究者氏名:龔 剣萍

3 研究の狙い:

本研究に先立って、ミオシンゲルとアクチンゲルの間に2次元的な接触を持つ巨大なアクチン 集合体が、 1 分子アクチンと同程度の速度 $(1 \mu \mathrm{m} / \mathrm{s})$ で協同的に動くことを発見した。本研究では、 このように人工的に再構築した自己組織化化学架橋筋肉蛋白ゲルを用いて、熱摇らぎ $\left(k_{B} T\right)$ 程度 のエネルギーで駆動するソフトナノマシンの実現を目標とした。具体的には、このアクチン集合体 の構造と運動特性の関係を明らかにし、運動制御が可能なソフトナノマシンの製作に挑む。

生物由来のミオシン分子、アクチン分子を化学修飾することにより、高次機能およびを熱的、機械 的、化学的安定性を付与し、同時に生体機械と同様のエネルギ一効率を有するソフトマイクロマ シンの創出を目指す。

4 研究成果:

1）筋肉タンパクを用いたゲルバイオマシーンの設計および作成

機能性高分子複合体である筋肉を1分子レベルまで分解することで得られるタンパク質分子ー アクチン・ミオシンーをそれぞれ自己組織化させながら化学架橋することで再構築型ゲルバイオマ シーンの作成を試みた。カチオン性ポリマーの導入により、アクチンが様々な形状(ワイヤー状・フ アイバー状・リング状)を有した数十ミクロンまでの巨大コンプレックスを形成することを明らかにし た。その巨大コンプレックスのサイズやモルフォロジーはカチオン性ポリマーの化学構造に依存す ることも解明した。ミオシンは自己組織化と同時にシェアストレスを印加することにより分子レベル の配向構造をもった数百ミクロンほどのファイバーを形成することがわかった。その配向性は印加 するシェアストレスの強さを変化させることで制御可能である。このようにして再構築された筋肉タ ンパクを化学的に架橋することで巨大アクチンゲルおよびミオシンゲルが得られ、これをゲルバイ オマシーンの運動素子とした。

2）ゲルバイオマシーンの生理学的キャラクタリゼーション

このように人エ的に再構築されたミオシンゲルは筋肉タンパク特有の生理活性(ATPase 活性) を保持しており、ミオシンゲル上においてアクチンが滑り運動をすることを明らかにした。さらに、ミ オシンゲル上でのアクチンの最大滑り運動速度はミオシンゲルの ATPase 活性に比例することを 明らかにした。

3） ゲルバイオマシーンの運動発現と運動制御

さらに配向ミオシンファイバーゲル上で、種々のポリカチオンにより作成した巨大アクチンゲルの 滑り運動発現に成功した。ネイティブアクチンと比べ 1.3 倍も速く滑り運動する巨大アチンゲルの作 成にも成功した。さらにネイティブアクチンの平均移動距離(L)は観測時間(タイムスケール)の $1 / 2$ 乗に比例するのに対し巨大アクチンゲルはほぼ 1 乗に比例しており、非常に高い運動方向性が示さ れた。

4）ゲルバイオマシーンの運動特性と集合体の構造との相関性

巨大アクチンゲル中の F-アクチンには極性を示すミオシンヘッド(HMM) 由来のやじり構造が観察 された。F-アクチン同士の極性は巨大アクチンゲルの作成の際に導入するカチオン性ポリマーの種 類で変化し、側鎖型ポリカチオンは極性の高いコンプレクスを、主鎖型ポリカチオンでは極性の低い ものを形成することが明らかになった。さらに巨大アクチンゲルの運動性は巨大アクチンゲルの極 性と非常に強い相関をもち、極性が高いほど運動速度が上昇することを明らかにした。

5）レーザーピンセット装置の構築と最適化

ミオシンゲル上で巨大アクチンゲルが滑り運動する際に発生するカを測定するため pN オーダ 
一のカを測定できるシステムをレーザーピンセットを用いて構築した。また ATP の潅流を可能とす るフローセルを作成した。その中で滑り運動を発現させ、その際に発生する力を測定する予定である。

5 自己評価:

筋肉蛋白アクチンとミオシンを基本 Building block として使い、人工的に再構築し、ATP 駆動型 ゲルマシンを作る発想と試みはこれまでに例がなく、世界で始めてである。そのため、このように 構築した筋肉蛋白ゲルが高い生理活性を保ち、ATP で動いた研究成果を Advanced Material 誌 に発表されてから、Nature 誌の Science Update やフランスの科学雑誌(Sciences Avenir)に紹介 されるほど世間に大きな着目を集めた。

本研究のようなナノ・メン゙スコピックのゲルマシンについての研究はその中間をつなぎ、これまで に筋肉で未解決の問題であるミオシン・アクチンすべり運動の機構、階層構造の役割、収縮の協 同性などを新しい視点から解決できる。筋肉蛋白の集合体が個々のものより高い運動性を示すこ とが階層構造創発(Emergence)に帰因するものと考えられる。

全体を通して、概ね計画したとおりで研究を推進したものの、筋肉蛋白ゲル同士の滑り運動に おいて、発生する力を定量的に測定することは考えていたより困難で、まだ実現されていない。ま た、研究を推進している過程で、2次元のカチオンゲル表面でアクチンが 3 次元的な網目を形成す る現象を発見した。この面白い現象を利用して、人工細胞骨格の構築やアクチン駆動システムの 創製などへ、今後しっかり展開していきたい。

\section{6 研究総括の見解:}

筋肉モデルとして電界に応答する人工材料の開発が行われ、また、生物的な筋肉たんぱく質 の動作機構の解明が行われてきたが、龔研究員は生物から抽出した筋肉たんぱく質を再組織化 して、組織構造と動作の関係を明らかにした。さらに、アクチンとミオシンの協同的滑り運動の可 視化技術は、筋肉たんぱく質の動作原理解明のための要素技術として重要である。このユニーク な研究は海外誌に取り上げられるなど、多くの研究者の関心を集めている。

7 主な論文等:(2002 年-2004 年)

主な原著論文

1) A. Kakugo, S. Sugimoto, K. Shikinaka, J. P. Gong, Y. Osada," Characteristics of Chemically Cross-linked Myosin Gels", J. of Biomater. Sci., in press.

2) A. Kakugo, K. Shikinaka, K. Matsumoto, J. P. Gong, Y. Osada, "Growth of Large Polymer-Actin Complexes", Bioconjugate Chem. 14,1185-1190(2003).

3) J. P. Gong, Y. Katsuyama, T. Kurokawa, Y. Osada, "Double Network Hydrogels with Extremely High Mechanical Strength”, Advanced Materials, 15,1155-1158(2003).

4) T. Kurokawa, J. P. Gong, Y. Osada, "Substrate Effect on Topographical, Elastic, and Frictional Properties of Hydrogels", Macromolecules, 35, 8161-8166(2002).

5) A. Kakugo, S. Sugimoto, J. P. Gong, Y. Osada, "Nanoactuators built of covalently bound myosin and actin gel fibers", Advanced Materials, 14, 1124-1126(2002).

他 19 編

総説 11 編、著書(共著) 3 編、基調講演·招待講演·特別講演 20 回、特許 10 件

新聞·雑誌にとり上げられた研究記事

1) “Muscle artificial enkit” SCIENCE ET AVENIR p20 Oct, 2002 (France の雑誌).

2) "Building up some muscle", Artificial muscle made from natural building blocks, Nature, Science update, 16, Aug, 2002.

3）「ゼラチンから軟骨一北大、人工軟骨に応用へ」, 日本経済新聞, 2003 年 5 月 26 日 
4）「動物たんぱくで人工筋肉作製」, 日経産業新聞, 2003 年 5 月 28 日

5) “Tough Gels”, Science, Editors' choice, 301, 1019(2003). 